O. POOTC

\title{
ПРЕДВАРИТЕЛЬНЫЙ РАСЧЕТ ГОДОВОГО БАЛАНСА ПОЛИХЛОРИРОВАННЫХ БИФЕНИЛОВ ДЛЯ БАЛТИИСКОГО МОРЯ
}

\author{
(Представил О. Эйзен)
}

Водный баланс Балтийского моря ( $\kappa \mu^{3}$ в год) выражается уравнением:

$$
\Theta_{1}+P+\Theta_{3}=E+\Theta_{2}
$$

где $\Theta_{1}-$ приток речных вод;

$P$ - осадки над морем;

$\Theta_{3}$ - приток из Северного моря;

$E$ - испарение с поверхности моря;

$\Theta_{2}$ - отлив в Северное море.

По данным А. Войпио и В. Дюберна, водный баланс Балтики следующий $\left(\kappa \mu^{3}\right.$ в год):

$$
\begin{aligned}
& 500+200+580=180+1100\left[{ }^{1}\right] \\
& 470+200+430=180+920\left[{ }^{2}\right]
\end{aligned}
$$

Общая площадь моря $365300 \kappa \mu^{2}$ и объем $21920 \kappa \mu^{3}\left[{ }^{3}\right]$.

Для изучения вопроса циркуляции полихлорированных бифенилов (ПХБ) в морской среде нами составлен предварительный годовой баланс этих химически устойчивых веществ для всей акватории Балтики:

а) приход: $\Theta_{1} c_{p}+\Theta_{4} c_{\mathrm{cт}}+\Theta_{8} c_{\text {под }}+P c_{0}$;

б) расход: $\left(\Theta_{2}-\Theta_{3}\right) c_{\mathrm{M}}+\Theta_{6} c_{\text {гид }}+E c^{\prime}{ }_{\mathrm{M}}+\left(\Theta_{5}-\Theta_{7}\right) c_{\text {дон }}$,

где $\Theta_{1}-$ приток речных вод;

$\Theta_{2}$ - отлив в Северное море;

$\Theta_{3}$ - приток из Северного моря;

$\Theta_{4}$ - сбросы сточных вод;

$\Theta_{5}$ - количество осажденных за год донных отложений;

$\Theta_{6}$ - количество выловленных за год гидробионтов;

$\Theta_{7}-$ количество продуктов эрозии дна и абразии берегов;

$\Theta_{8}$ - подземный сток;

$E$ - испарение с поверхности моря;

$P$ - осадки над морем;

$c_{\mathrm{p}}$ - концентрация ПХБ в речной воде;

$c_{\mathrm{o}}$ - концентрация ПХБ в осадках;

$c_{\text {под }}-$ концентрация ПХБ в подземном стоке;

$c_{\text {ст }}$ - концентрация ПХБ в сточной воде; 
$c_{\text {дон }}-$ концентрация ПХБ в донных отложениях;

$c_{\text {гид }}-$ концентрация ПХБ в гидробионтах;

$c^{\prime}{ }_{\text {м }}$ - концентрация ПХБ в поверхностной пленке морской воды;

$c_{\mathrm{M}}$ - концентрация ПХБ в морской воде Датских проливов.

Приток ПХБ в Балтийское море осуществляется главным образом четырьмя путями: из атмосферы, речным стоком, сточными водами и подземным стоком. Средний месячный приток ПХБ из атмосферы в поверхностные слои моря составляет $2000 \mathrm{Hг} / \mathrm{s}^{2}$ (около промышленных районов южной Балтики даже до $\left.10000 \mathrm{\mu z} / \mathrm{M}^{2}\right)$ [ $\left.{ }^{4}\right]$. Каждый год в Балтийское море поступает из атмосферы 8,80 т химиката. Средний годовой речной сток составляет 440-472 км³ [3]. По данным М. Ахнхоффена и Б. Иозефсона [5], концентрации ПХБ в речной воде колеблются в пределах $0,3-1,2$ нг/ $[5]$, следовательно, с речным стоком в море поступает $0,13-0,57$ т ПХБ.

Общее количество полихлорированных бифенилов, попавших в Балтийское море со сточными водами, можно вычислить косвенным путем. Прямое отношение к попаданию хлорорганики в морскую среду имеют судовые краски, суммарное количество которых $(15 T)$ использовали в 1969 году в Швеции [6]. Если считать, что в морскую среду Балтики попадает около $1 \%$ этого количества и что прибрежная зона Швеции охватывает одну треть общей береговой линии Балтики, то судовые краски выделяют в море 0,45 $т$ ПХБ. Учтенные запасы ПХБ в Балтике составляют $1620-1770$ т (вычислены в расчете на чистый вес вещества). Почти $90 \%$ этих запасов используется в закрытых системах (для трансформаторных масел и т. д.), поэтому количество ПХБ в сточных водах ничтожно мало $(0,01 \%)$. Ежегодно вместе со сточными водами поступает суммарно не более $0,63 T$ ПХБ (в ряде стран использование и ввоз полихлорированных бифенилов строго контролируются, поэтому в ближайшее время их количество в сточных водах должно понизиться). Подземным стоком можно пренебречь, так как в общем стоке он играет незначительную роль (3-4 км ${ }^{3}$ в год) [7].

Расход ПХБ Балтийского моря совершается четырьмя путями: испарением, отливом в Северное море, вылавливанием гидробионтов и осаждением на дно моря. Морские испарения ежегодно составляют $180 \kappa м^{3}$ при средних концентрациях ПХБ на поверхностной пленке моря 20-25 нг/л. Суммарное количество хлорорганики, поступающей в атмосферу, 3,6-4,5 т в год. Концентрации ПХБ в морской воде Центральной Балтики и в Датских проливах, по нашим данным и данным других авторов, колеблется в пределах 1,4-9,9 нг/л (в среднем 5,6 нг/л) $\left[{ }^{8,9}\right]$. Таким образом, отлив в Северное море выносит $2,7-2,9$ т ПХБ.

Годовые уловы рыбы и беспозвоночных составляют 928880 T [10, $\left.{ }^{11}\right]$ При средних концентрациях ПХБ в гидробионтах $0,25-0,40$ мг/ке [12-14] общее количество бифенилов в выловленных гидробионтах составляет $0,23-0,37 \tau$.

Рассчитаем годовой баланс полихлорированных бифенилов для Балтийского моря.

Приход:

Общее количество, $T$

атмосферный приток

речной сток

сточные воды

приток из Северного моря
8,80

$0,13-0,57$

$0,61-0,63$

$2,41-3,25$ 
Р а с ход:

отлив в Северное море

вылавливание гидробионтов

испарение с поверхности моря

осаждение с взвешенными веществами
Общее количество, $т$

$$
\begin{aligned}
& 5,15-6,16 \\
& 0,23-0,37 \\
& 3,60-4,50 \\
& 0,15-0,41
\end{aligned}
$$

Очень трудно определить общее количество осажденных на дно взвешенных веществ. Определяемая величина представляет собой разницу осажденных на дно веществ и веществ, поступающих со дна в воду. По данным [7], годовая разница составляет $5,1 \times 10^{6} T$ терригенного осадочного материала. Концентрации ПХБ в донных отложениях Балтики (в верхнем слое) $30-80 \mathrm{Hz/2}\left[{ }^{15}\right]$. На дно осаждается каждый год $0,15-0,41 \tau$ ПХБ.

Полученные результаты показывают, что разница прихода и расхода составляет $0,51-4,12$. Если это количество равномерно распределить в общем объеме морской воды, то увеличение концентрации ПХБ в ней не может быть значительным, максимально 0,18 нг/ $\Omega$ в год. Но нельзя забывать, что источники загрязнения ПХБ в Балтийском море локальны, поэтому концентрации могут увеличиваться в этих районах моря на несколько порядков. В дальнейшем при расчете годового баланса циркуляции ПХБ в морской среде основное внимание следует уделить границам разделов: атмосфера-поверхностные слои моря и морское дно-придонный слой.

\section{ЛИТЕР А Т Р А}

1. Vo ip io, A. On the cycle and the balance of phosphorus in the Baltic Sea. - Suomen Kemistilehti, 1969 , v. A-42, p. $48-53$.

2. D y ber n, B. I. Pollution in the Baltic. - FAO Technical Conference on Marine Pollution and Its Effects on Living Recources and Fishing, Rome, 9-18 Dec., 1970, FIR:MP (70), R-3, 1970, p. 1-17.

3. Я рвекюльг А. Донная фауна восточной части Балтийского моря. Таллин, 1979 , c. $27-33$.

4. Södergre n, A. PCB in airbone fallout. - In: PCB Conference 2, Stockholm, 1972, p. $15-18$.

5. A h n h of f, M., Jos ef f s o n, B. PCB in Göta River water. - Ambio, 1975, v. 4, p. $17-175$.

6. Jen sen, S. The PCB story. - Ambio, 1972, v. 1, N 4, p. 123-131.

7. Гуделис В. К., Е мелян о в Е. М. Геология Балтийского моря, Вильнюс, 1976 , c. $120-187$.

8. Osterroht, C. Dissolved PCB-s and chlorinated hydrocarbons insecticides in the Baltic, determined by two different sampling procedures. - Marine Chem., 1977, v. 5 , p. $113-121$.

9. St a d l e r, D. F. Chlorinated hydrocarbon in the seawater of the German Bight and the western Baltic in 1975. - Dtsch. hydrogr. Z. 1977. H. 6, p. 189-215.

10. International council for the exploration of the sea. - In: Cooperative research report. Denmark, 1979, N 85, p. 131-149.

11. Kihlstrom, J. E., Berglund, E. An estimation of the amounts of the PCB in the biomass of the Baltic. - Ambio, 1978, v. 7, N 4, p. 175-178.

12. $\mathrm{P}$ оот с О. О., Пе й к ре Э. А. О содержании полихлорированных бифенилов и хлорорганических пестицидов в рыбах Балтийского моря. - Изв. АН ЭССР. Хим., 1978, т. 27 , № 3 , с. $193-196$.

13. International council for the exploration of the sea. - In: Cooperative research report. Denmark, 1977, N 63, p. 1-79.

14. Jensen, S., Johnels, A., Ol isson, M., Otterlind, G. DDT and PCB in herring and cod from the Baltic, the Kattegat and the Skagerrak. - Ambio (Special Report), 1972, N 1, p. 71-87.

15. Oden, S., Berggren, B. PCB and DDT in Baltic sediments. The 2nd SwedishSoviet Symposium on protection of the Baltic from pollution, Riga 1973, p. 1-10.

Ннститут термофизики и электрофизики Академии наук Эстонской ССР 


\section{O. ROOTS}

\section{LAANEMERES SISALDUVATE POLUKLOREERITUD BIFENUULIDE AASTASE BILANSI ARVUTAMINE}

Artiklis esitatud andmeil toimub polükloreeritud bifenüülide (PCB) juurdevool Läänemerre nelja teed pidi: atmosfäärist $(8,8$ tonni aastas), jõgedega $(0,13-0,57 \mathrm{t})$, heitvetega $(0,61-$ 0,63 t) ja Põhjamerest $(2,41-3,25$ t). Ka PCB eraldumine mereveest toimub neljal viisil: aurumine mere pinnalt $(3,6-4,5 \mathrm{t})$, sadestumine mere põhja hõljumiga $(0,15-0,41 \mathrm{t})$, väljapüütud kalade ja molluskitega $(0,23-0,37 \mathrm{t}) \mathrm{ja}$ väljavooluga Pổhjamerre $(5,15-$ $6,16 \mathrm{t})$.

\section{O. ROOTS}

\section{PRELIMINARY INVESTIGATION OF THE ANNUAL BALANCE OF POLYCHLORINATED BIPHENYLS (PCB) IN THE BALTIC SEA}

The author compiled the annual balance of PCB in the Baltic. The inflow of PCB in the Baltic proceeded in four ways: in the atmosphere $(8.8 \mathrm{t})$, with the water of rivers $(0.13$ $0.57 \mathrm{t})$, with the sewage $(0.61-0.63 \mathrm{t})$ and inflow of water from the North Sea $(2.41-$ $3.25 \mathrm{t}$ ). The outflow of PCB proceeded likewise in four ways: by evaporation on the surface of the sea $(3.6-4.5 \mathrm{t})$, fallout onto the sea bottom $(0.15-0.41 \mathrm{t})$, with the caught fish and molluscs $(0.23-0.37 \mathrm{t})$ and with outflowing water of the Baltic into the North Sea $(5.15-6.16 \mathrm{t})$. 